DR. BRUNO KREISKY LECTURESERIESII 2 $\cdots+3^{3}$

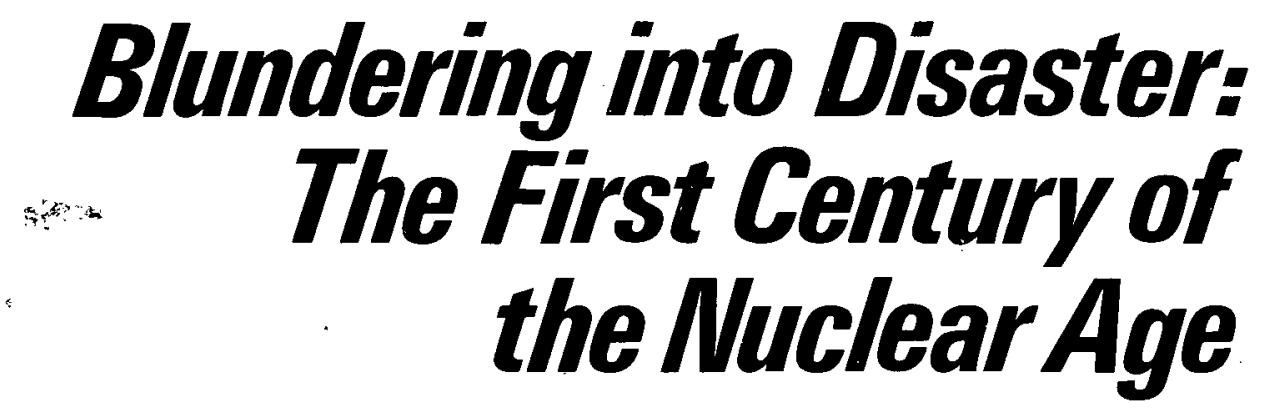

ROBERTS. MCNAMARA 
$*$ 


\section{Blundering into Disaster: The First Century of the Nuclear Age}




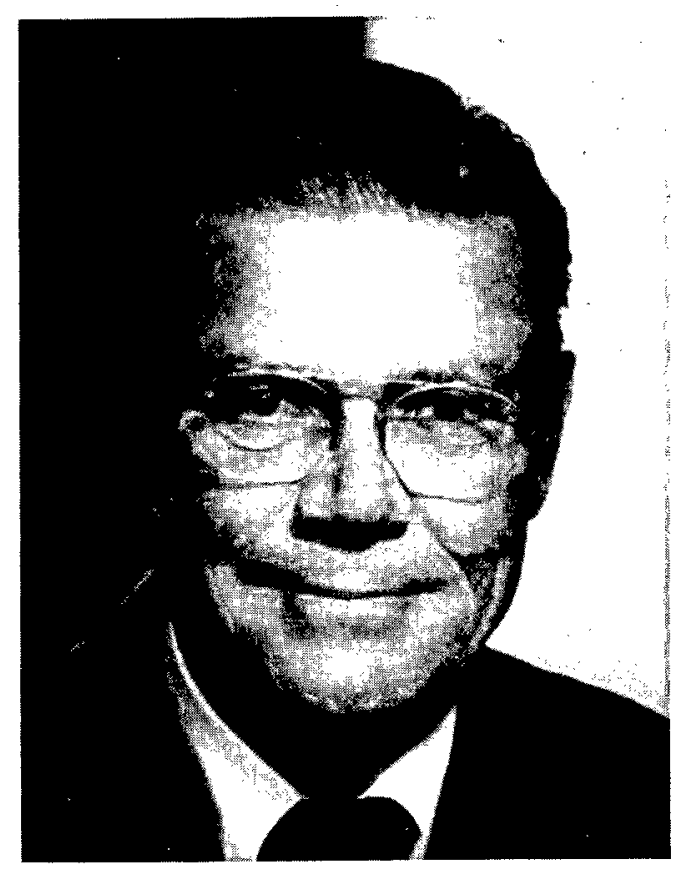

ROBERT S. MC NAMARA

$$
5 .
$$




\section{Blundering into Disaster: The First Century of the Nuclear Age}

LAXENBURG, NOVEMBER 17, 1986

\section{ROBERTS. MCNAMARA}




$$
\therefore
$$

ISBN 3-7045-0080-1

Copyright @ International Institute for Applied Systems Analysis 1987

All rights reserved. No part of this publication may be reproduced or transmitted in any form or by any means, electronic or mechanical, including photocopy, recording, or any information storage or retrieval system, without permission in writing from the copyright holder.

Printed by Novographic, Vienna, Austria 


\section{FOREWORD}

This is the second distinguished lecture in IIASA's Dr. Bruno Kreisky Lecture Series. In the first one, Chancellor Kreisky addressed the issue of détente between the superpowers. In this lecture, Secretary McNamara will discuss the most burning issue mankind ever faced: can our civilization survive in the nuclear age? Mr. McNamara is eminently qualified to discuss this issue, since, as US Secretary of Defense, he was involved in the early arms control discussions between the USA and the USSR during the 1960s.

In this lecture, he addresses such fundamental issues as the instability that may be introduced by combining offensive weapons and defensive systems, particularly as contemplated in the US Strategic Defense Initiative (SDI). Mr. McNamara's view represents a very important side of the ongoing debate, and the reader will find his arguments illuminating and instructive.

IIASA is pleased to welcome such a distinguished speaker for the second Dr. Bruno Kreisky Lecture.

Thomas H. Lee

Director

International Institute for Applied Systems Analysis 
5 


\section{INTRODUCTION}

Last year I had the opportunity to express my pleasure that this grand institution had established a lecture series under my name. I was the first speaker, and I am very honored and deeply touched that the second lecture is being given by such an outstanding personality as Mr. McNamara.

I shall try to characterize one of the most remarkable men of our time in just a few sentences. I still remember when he was appointed to serve in the US government. At that time the world was still a bit astonished that someone from Big Business would accept a public service position, and one was curious how this would work out. It very soon turned out that Mr. McNamara was as efficient in his political function as he had been in business, and that his way of thinking in this particularly sensitive department (Defense) differed considerably from that of many other ministers in this field. He created a new spirit, and what impressed us most was that, from the very beginning, he was aware of the major change in armament technology - that these new weapons were no longer weapons in the traditional sense, but something entirely different.

From then on, many of us realized that we were at the beginning of a new era that would lead either to mutual understanding or to disaster. He helped us to understand that.

Now I should like to turn to Mr. McNamara's tenure at the World Bank. No one before or after him managed this large institution with his spirit. He recognized the magnitude of the problems and the resulting depth of the abyss - the problems and the abyss between the industrialized and the developing countries. That was a good period for the World Bank. Perhaps it was not "profit making", as it is today, but it fulfilled its function in the spirit of its founders. And it was Mr. McNamara who made possible the famous Brandt Commission Report. I do not give him sole credit for proposing entirely new approaches, but it was surely Mr. McNamara's efforts that made possible the document that has become the essence of modern, target-oriented development policy. I am deeply convinced that the contents of this document show us the way out of the one-way street into which earlier development policy had led. This is manifested in many ways.

I would like to say that I was particularly happy to have the opportunity to participate in the International Commission of the Aspen Institute for some time (illness prevented me from participating longer and more actively). Thanks to Mr. McNamara's participation, this group of men and women raised their voices against a further ideolog. ization of foreign policy and in support of a policy of approximation.

In concluding, let me say that I believe the time has come for a major rapprochement between East and West. It must not be said in a few years that we should have done 
it then. I therefore express the hope, and I do so because I know Mr. McNamara's points of view and grand perspectives, that the rapprochement will soon develop in the spirit that he has proclaimed time and again.

Dr. Bruno Kreisky<smiles>[13CH3][13CH3]</smiles> 


\title{
BLUNDERING INTO DISASTER: The First Century of the Nuclear Age*
}

\author{
ROBERT S. MCNAMARA
}

I was delighted to receive the invitation to deliver IIASA's second Kreisky Lecture - delighted because it provides me with an opportunity to express my respect and admiration for both Chancellor Kreisky and for the Institute.

For more than a quarter of a century Bruno Kreisky has been a leading exponent of East-West détente. It was under his leadership that Vienna became an international meeting place. And it was in this connection that he successfully argued that Austria was IIASA's natural home. His interest in, and concern for, IIASA did much to ensure that this experiment in East-West scientific cooperation would evolve into a successful, consequential international research center. For that and his numerous other achievements in the international sphere, we and our children and grandchildren will be in his debt for decades to come.

This evening I want to address the question: Is the risk of nuclear war unacceptably high and, if so, what can we in the West as well as those in the East do about it? Will Reykjavik prove to be a step toward reducing that risk?

Let me begin by recalling that it is nearly 50 years since Albert Einstein sent his historic letter to President Roosevelt warning him that it was essential that the United States move quickly to develop the nuclear bomb. In that half century the world's inventory of such weapons has increased from zero to 50,000 . On average, each of them has a destructive power 30 times that of the Hiroshima bomb. A few hundred of the 50,000 could destroy not only the United States, the Soviet Union, and their allies, but, through atmospheric effects, a major part of the rest of the world as well.

The weapons are widely deployed. They are supported by warfighting strategies. Detailed war plans for their use are in the hands of the field commanders. And the troops of each side routinely undertake exercises specifically designed to prepare for that use. General Bernard Rogers, the Supreme Allied Commander of NATO forces in Europe, has said it is likely that in the early hours of a military conflict in Western Europe, he would in fact ask for the authority to initiate such use.

This situation has evolved over the years through a series of incremental decisions. I myself participated in many of them. Each of the decisions, taken by itself, appeared rational or inescapable. But the fact is that they were made without reference to any overall master plan or long-term objective. They have led to nuclear arsenals and nuclear war plans that few of the participants either anticipated or would, in retrospect, wish to support.

*This lecture is based on Blundering into Disaster by Robert S. McNamara, published in October 1986. 
Because East and West lack a long-run plan for the nuclear age, the number of weapons continues to multiply. And now we appear on the verge of an escalation of the arms race that will not only place weapons in space, but will seriously increase the risk that one or the other of the adversaries will be tempted, in a period of tension, to initiate a preemptive nuclear strike before the opponent can get in the first blow.

Although four decades have passed without the use of nuclear weapons, and although it is clear that both the United States and the Soviet Union are aware of the dangers of nuclear war, it is equally true that for thousands of years the human race has engaged in war. There is no sign that this is about to change. And history is replete with examples of occasions in such wars when emotions have taken hold and replaced reason.

I do not believe the Soviet Union wants war with the West. And certainly the West will not attack the Soviet Union or its allies. But dangerous frictions between East and West have developed in the past and are likely to do so in the future. If deterrence fails and conflict develops, the present strategies of NATO and the Warsaw Pact carry with them a high risk that civilization will be destroyed.

During the seven years I served as Secretary of Defense, confrontations carrying a serious risk of military conflict developed on three separate occasions: over Berlin in August of 1961 ; over the introduction of Soviet missiles into Cuba in October of 1962; and in the Middle East in June of 1967. In none of these cases did either side want war. In each of them we came perilously close to it.

Let me describe one of them to you in order to illustrate the point I wish to make.

On October 14, 1962, a US U-2 aircraft, flying a reconnaissance mission, obtained photographic evidence that the Soviet Union had moved nuclear missiles into Cuba. Their range would permit them to attack the most heavily populated regions on the East Coast.

It is true that at that time we had a strategic nuclear force of approximately 5,000 warheads compared with the Soviet Union's 300. But despite this numerical superiority of 17 to one, we did not believe we had a capability to launch a successful "first strike" against the Soviet Union. It is possible, nevertheless, that the Soviets feared we might do so. Driven by that fear, they may have sought to increase the size of their retaliatory force by moving relatively short-range missiles from Soviet soil to Cuba, thereby increasing the number of weapons threatening our shores.

In any event, because the United States had been "deterred" from a first strike by the force balances that had existed prior to the introduction of the weapons into Cuba, that action, in the opinion of many in the Administration, did not change the military balance. It did, however, represent a political move that, it was believed, must be reversed.

There were two schools of thought on how this should be done.

One group, which included the majority of President Kennedy's advisors, believed that we should seek to destroy the missiles by an air attack. It was recognized that such an attack would almost certainly require a follow-up ground invasion that might result in 25,000 US casualties and a corresponding number of Cubans dead or wounded. Further, it was believed that while our military superiority in the hemisphere would assure the success of the air attacks and the land invasion, the Soviet Union would very likely respond by military action against the flanks or even the center of NATO. 
Those who opposed the air attacks recommended a quarantine designed to prevent the Soviet resupply of Cuba until the missiles were withdrawn.

The President chose the second option.

The quarantine was put in place on October 24, 1962. On October 25, a Soviet tanker approached a designated quarantine line and refused to stop despite the presence of a US destroyer on its quarter. The immediate question was: How should the United States react? Some proposed that we force the vessel to halt by gunfire. Others suggested that we not push the Soviets into a corner at that stage, but give their leadership more opportunity to react to our position and ample time to communicate their decision to all their vessels at sea.

The tanker was allowed to "pass through" the line.

Diplomatic exchanges continued.

On Friday evening, October 26, we received the most extraordinary diplomatic message I have ever seen. The teletype was six or seven feet in length. It was a long, ram. bling message signed by Khrushchev. The text had obviously been dictated by a man under intense emotional pressure. Khrushchev said "We are both engaged in a tug-of-war, pulling on either end of a rope and thereby tying a knot that, once tied, neither of us will ever be able to undo." He was saying that events, were they to continue, would inevitably lead to war. And he added, "If war should break out, it would not be in our power to stop it - war ends when it has rolled through cities and villages, everywhere sowing death and destruction."

On Saturday morning a second message arrived. It was tougher, more coldly threatening, and clearly the reflection of a group decision rather than the words of a single individual.

Tensions continued to rise that Saturday. New photographs suggested that the Soviets were continuing work on installing the missiles. US forces in Florida prepared for an invasion of Cuba. Another Soviet ship was heading toward the quarantine line. Mean while, our naval antisubmarine forces in the Caribbean were closely tracking Soviet submarines and had forced five or six of them to surface near the quarantine zone.

We then learned that one of our U-2 planes had been shot dowñ over Cuba by a Soviet surface-to-air missile. The pilot was killed. A second U-2, flying from Alaska to the North Pole, strayed over Soviet territory and drew a crowd of Soviet fighter planes before regaining its course.

Against this background we chose to reply to Khrushchev's original, less threatening communication, emphasizing that we had no intention of invading Cuba if the Soviet offensive forces were removed. But we made clear that if they were not removed, further action by the United States would follow.

I will not speculate on what that further action might have been, but I do know that as I left the White House and walked through the garden to my car to return to the Pentagon on that beautiful fall evening, I feared I might never live to see another Saturday night.

I do not wish to indicate that there was the slightest possibility that, had military action followed, we would have initiated the use of nuclear weapons. Nor do I wish to suggest that we believed the Politburo, even in the face of US air and sea attacks, would 
have authorized launching the Cuban-based missiles against our East Coast cities. But who could say that, with his forces about to be destroyed, a Soviet or Cuban lieutenant on the scene would not have given the order to fire?

On Sunday Khrushchev informed the President that he had issued orders to dismantle the missile bases and remove the missiles and bomber aircraft from Cuba. The crisis was over.

In no one of the three incidents I have referred to - Berlin, Cuba, and the Middle East - did either side intend to act in a way that would lead to military conflict; but on each of the occasions lack of information, misinformation, and misjudgments led to confrontation. And in each of them, as the crisis evolved, tensions heightened, emotions rose, and the danger of irrational decisions increased.

It is correct to say that no well-informed, coolly rational political or military leader is likely to initiate the use of nuclear weapons. But political and military leaders, in moments of severe crisis, are likely to be neither well-informed nor coolly rational.

In 1962 President Kennedy insisted that each member of the National Security Council read Barbara Tuchman's The Guns of August. The book is the story of how the nations of Europe inadvertently blundered into World War I. The author begins by quoting Bismarck's comment that "some damned foolish thing in the Balkans" would ignite the next.war. She then relates the series of steps - following the assassination on June 28 , 1914, of the Austrian heir apparent, Archduke Franz Ferdinand, by Serbian nationalists - each small and insignificant in itself, which led to the most appalling military conflict in the history of the world. Time and again, at the brink of hostilities, the chiefs of state tried to pull back, but the momentum of events dragged them forward.

President Kennedy reminded us of the 1914 conversation between two German chancellors on the origins of that war. One asked, "How did it happen?" and his successor replied, "Ah, if we only knew." It was Kennedy's way of stressing the constant danger of miscalculation.

Today we face a future in which for decades we must contemplate continuing confrontation between East and West. Any one of these confrontations can escalate, through miscalculation, into military conflict. And that conflict will be between blocs that possess 50,000 nuclear warheads - warheads that are deployed on the battlefields and integrated into the war plans. A single nuclear-armed submarine of either side would unleash more firepower than man has shot against man throughout history.

In the tense atmosphere of a crisis, each side will feel pressure to delegate authority to fire nuclear weapons to battlefield commanders. As the likelihood of attack increases, these commanders will face a desperate dilemma: use the weapons or lose them. And because the strategic nuclear forces, and the complex systems designed to command and control them," are perceived by many to be vulnerable to a preemptive attack, they will argue the advantage of a preemptive strike.

But it is a fact that in the face of the Soviet nuclear forces the West has not found it possible to develop plans for the use of its own nuclear weapons in a conflict with the Soviet Union in ways that would both assure a clear advantage to the West and at the same time avoid the very high risk of escalating to all-out nuclear war. It would be safe to assume that Moscow confronts a similar dilemma. 
What would be the consequences of such a conflict?

Studies by two of my former aides in the Pentagon concluded that, even under the most favorable assumptions, there is a high risk of 100 million dead. Such studies prompted Helmut Schmidt to remark that the use of nuclear weapons will not defend the West, but destroy it.

And they led not only Field Marshal Lord Carver, but also Lord Louis Mountbatten and several other of the eight retired Chiefs of the British Defense Staff, to indicate that under no circumstances would they have recommended that the West initiate the use of nuclear weapons in a confrontation with the Soviet Union.

The risk that military conflict will quickly evolve into nuclear war, leading to certain destruction of our civilization, is far greater than I am willing to accept on military, political, or moral grounds. And, I submit, it is far greater than you should be willing to continue to accept.

The conviction, therefore, that the major powers must change course is shared by groups and individuals as diverse as the antinuclear movements, the majority of the world's top scientists, Soviet General Secretary Mikhail Gorbachev and US President Ronald Reagan, and such leaders of Third World and independent nations as Rajiv Gandhi and the late Olof Palme. All agree that we need a plan to reduce the long-term risk of nuclear war, but there is no consensus on what course to take. The changes of directions being advocated follow from very different diagnoses of our predicament.

Before examining proposals for changing course, it should be emphasized that if the superpowers continue to weaken the arms control regime, as they have over the past six or seven years, the risk of the world ultimately facing a nuclear conflagration will continue to grow.

Miniaturization is increasing the mobility, accuracy, and destructive power of weapons. In advanced stages of development are mobile land-based missiles; antisatellite weapons; space-based systems; and land-, sea-, and air-based cruise missiles that are increasingly difficult to limit by verifiable arms control agreements.

The current nuclear weapons building program of the United States, which is producing 2,000 warheads annually, is the biggest in 20 years. And steps are under way to expand substantially, for the 1990 s, both the production of the key nuclear materials tritium, uranium, and plutonium - and the production of the warheads themselves. At the same time, our weapons laboratories are forecasting large increases in the number of underground tests required for the development of new types of nuclear arms.

Unconstrained weapons development and deployment over the next 50 years will lead not only to increased numbers of weapons, but also to a greater danger of their use in times of tension. This, in turn, will result in greater crisis instability.

It is the recognition of this danger that has led the President, the General Secretary, and others to suggest actions that they hope will reduce the long-term risk of nuclear war. The proposals they have presented include:

1. Achieving political reconciliation between East and West.

2. Eliminating all nuclear weapons through negotiation (as proposed by General Secretary Gorbachev). 
3. Replacing "deterrence" with "defense" - the elimination of nuclear weapons by the substitution of defensive forces for offensive forces (as proposed by President Reagan).

4. Strengthening deterrence by adding defensive forces to the offense (as proposed by Henry Kissinger and others).

5. Accepting the proposition that nuclear warheads have no military use whatsoever, except to deter one's opponent's use of such weapons.

Do any of these alternatives offer hope that the risk of nuclear war can be significantly reduced in the second half century of the nuclear age?

Before discussing the choices we in the West face, we should erase from our minds a series of misperceptions of the nuclear balance between East and West that are widespread, both in the United States and throughout Western Europe. They include such commonly held views as:

- The Soviets possess nuclear forces superior to our own.

- The Soviets possess, or are seeking to achieve, a first-strike capability.

- Regardless of US actions or restraint, the Soviets will continue to expand their nuclear power as quickly as they can for as long as they can.

- If the West mobilizes its technical resources, it can achieve and maintain a militarily significant lead over the Soviets.

- Given the political confrontation between East and West, the buildup of nuclear forces to their present level was inevitable.

- Arms control agreements are worthless - the Soviets cheat and their violations are undetectable.

- Arms control agreements have only led to Soviet advances.

- Nuclear weapons, even when militarily irrelevant, may serve political ends.

All of these statements are incorrect.

But the arms race in the first half century of the nuclear age has been fueled in part by myths such as these. If we continue on this path for another 50 years, we will be led not only to further increases in the numbers of weapons, but also to a greater danger of their use in times of tension.

Let me now turn to a discussion of alternatives to this prospect.

\section{EAST-WEST RECONCILIATION Sision}

The East-West military rivalry, is, of course, a function of the political conflict that divides the two blocs. Many have argued, therefore, that any long-term attempt to bring a halt to the arms race and to reduce the risk of nuclear war must begin by addressing the source of the tensions - the political rivalry.

It is clear that the West - North America, Western Europe, and Japan - lacks an agreed conceptual framework for the management of relations with the Soviet Union and 
its allies. The West needs a coherent, widely supported policy, rooted in reality and pressed with conviction and determination. It must be a policy that protects vital interests, enhances political cohesion, and offers the hope of influencing the Soviets to move in a favorable direction. A long-term, stable relationship between East and West is both desirable and attainable. Even in an atmosphere of competition and mutual suspicion there are common interests, and the pursuit of each side's competitive goals can take place in an atmosphere of moderation.

The relationship must rest on the twin pillars of firmness and flexibility. It is abundantly clear that both of these elements are essential if our policies are to command public support and have a chance of succeeding. There is not a contradiction here: détente without defense would amount to surrender on the installment plan; defense without détente would increase tensions and the risk of conflict. The two are mutually reinforcing.

Therefore, I strongly urge that the West embark upon a program of "sustained engagement". It cannot be stressed enough, however, that this process will require time, patience, and consistency of purpose. And there are limits to the results. It cannot be expected to eliminate the periods of tension and confrontation that have characterized East-West relations over the past four decades. It is not, therefore, a substitute for other actions designed to reduce the risk that military conflict, rising out of such confrontation, will lead to the use of nuclear weapons. Steps to control directly and reverse the arms race must go forward in parallel with efforts to reduce political tension.

I turn next, therefore, to consideration of the four different approaches to controlling directly the "volume" and "use" of such weaponry.

\section{GORBACHEV: ELIMINATE ALL NUCLEAR WEAPONS}

Mikhail Gorbachev, General Secretary of the Soviet Communist Party, has proposed that the United States and the Soviet Union aim at achieving the total elimination of nuclear weapons by the year 2000 .

Is a nuclear-free world desirable, if attainable? I believe it is, and I think most Americans and most West Europeans would agree.

However, NATO's current military strategy and war plans are based on the opposite premise. And many - I would say most - US military and civilian officials, as well as Western European leaders, hold the view that nuclear weapons are necessary to deter Soviet aggression with conventional forces. Thus, these individuals do not favor a world without nuclear weapons. Zbigniew Brzezinski, President Carter's national security advisor, said of Gorbachev's proposal, "It is a plan for making the world safe for conventional warfare. I am therefore not enthusiastic about it."

My criticism of Gorbachev's vision, however, is not that it is undesirable, but that it is infeasible under foreseeable circumstances.

Unless technologies and procedures can be developed to ensure detection of any steps toward building a single nuclear bomb by any nation or terrorist group, an agreement for total nuclear disarmament will almost certainly degenerate into an unstable 
rearmament race. Thus, despite the desirability of a world without nuclear weapons, an agreement to that end does not appear feasible either today or for the foreseeable future.

\section{REAGAN: SUBSTITUTE DEFENSIVE FORCES FOR OFFENSIVE FORCES}

On March 23, 1983, President Reagan proposed his solution to the problem of security in the nuclear age. He launched the Strategic Defense Initiative (SDI), a vast program that promised to create an impenetrable shield to protect the entire nation against a missile attack. With the shield in place, the President argued, we would be able to discard not just nuclear deterrence, but nuclear weapons themselves.

The President and his Secretary of Defense, Caspar Weinberger, continue to promise that this strategic revolution is at hand.

Virtually all others associated with the SDI have recognized and admitted that such a leakproof defense is so far in the future, if indeed it ever proves feasible, that it offers no solution whatsoever to our present dilemma. Therefore, they are advocating missions for a Star Wars system other than a perfect "security shield". These alternative aims range from defense of hardened targets - for example, missile silos and command centers - to partial protection of our populations.

For the sake of clarity I will call these alternative programs Star Wars II, to distinguish them from the President's original proposal, which I will call Star Wars I. A third quite different version of SDI, which might be called Star Wars III, was put forward at Reykjavik.

It is essential to understand that Star Wars I and Star Wars II have diametrically opposite objectives. The President's program, if achieved, would substitute defensive for offensive forces. In contrast, Star Wars II systems have one characteristic in common: they would all require that we continue to maintain offensive forces, but add the defensive systems to them.

Until there are inventions that have not yet been imagined, a defense robust and cheap enough to replace deterrence will remain an illusion. Given that harsh reality, President Reagan's claims that defensive forces are "morally preferable" to offensive forces and that we have a "moral obligation" to pusue them are, as James Schlesinger has put it, "pernicious." Thus, "mutual assured destruction" is not, as some have alleged, an immoral policy. Mutual assured destruction - the vulnerability of each superpower to the awesome destructive power of nuclear weapons - is not a policy at all. It is a grim fact of life.<smiles>[14CH3]</smiles>

\section{STRENGTHEN DETERRENCE}

Former Secretary of State Henry Kissinger agrees that the achievement of Star Wars I in any time period relevant to our current problem is impossible. But Kissinger has become a supporter of Star Wars II. He believes that deploying strategic defenses, while maintaining offensive systems, will strengthen deterrence. 
The most powerful argument put forward by those who favor "offense plus defense" (i.e., Star Wars II) is that presented by Kissinger: even a partially effective defense would thereby enhance deterrence. This assumes that the Soviet military's sole concern is to attack us and that any uncertainty in their minds is therefore to our advantage. But any suspicions they may harbor about our wishing to achieve a first-strike capability - and they do, indeed, hold such views - would be inflamed by a partially effective defense.

Why will the Soviets suspect that Star Wars II is designed to support a first-strike strategy? Because a leaky umbrella offers no protection in a downpour, but is quite useful in a drizzle. That is, such a defense would collapse under a full-scale Soviet first strike, but might cope adequately with the depleted Soviet forces that had survived a US first strike.

And that is what causes the problem. President Reagan, in a little-remembered sentence in his March 23, 1983, speech, said, "If paired with offensive systems, [defensive systems] can be viewed as fostering an aggressive policy, and no one wants that." The President was concerned that the Soviets would regard a decision to supplement rather than replace - our offensive forces with defensive ones as an attempt to achieve a first-strike capability. Reagan has subsequently said, "I think that would be the most dangerous thing in the world, for either one of us to be seen as having the capacity for a first strike." But that is exactly how Moscow is interpreting the US program.

If the Soviets do not accept the statements of those who support Star Wars II - if they do not accept that SDI is not part of a first-strike strategy, but only a means of strengthening deterrence - how will they respond?

It would be foolhardy for Washington to dismiss as mere propaganda Moscow's repeated warnings that a nationwide US strategic defense is highly provocative. Their promise to respond with a large offensive buildup is no empty threat. Each superpower's highest priority has been a nuclear arsenal that can assuredly penetrate to its opponent's vital assets. Such a capability, each side believes, is needed to deter the other side from launching a nuclear attack or using a nuclear advantage for political gain.

We have said we would respond to a Soviet stategic defense plan in exactly the same way as they have stated they would respond to ours. We can safely conclude, therefore, from both the US and Soviet statements, that any attempt to strengthen deterrence by adding strategic defensive to strategic offensive forces will lead to a rapid escalation of the arms race.

To meet the threat of arms escalation, Paul Nitze, President Reagan's arms control advisor, has articulated a new US "strategic concept" for a cooperative shift to a Star Wars world: "What we have in mind is a jointly managed transition, in which the United States and the Soviet Union would together phase in new defenses in a controlled manner while continuing to reduce offensive nuclear arms." The President has gone further by proposing a delay in the deployment of Star Wars until all offensive ballistic missiles have been destroyed.

Although Nitze has made it clear that strategic defensive forces should not be deployed other than in accordance with the terms of an arms control agreement, no human mind has conceived of how to write such a treaty. Nitze himself has said that the transition to Star Wars would be "tricky": 
Why has no one been able to outline the content of such a treaty? Because neither US nor Soviet experts can figure out how both to reduce offensive forces and permit defensive deployment, while at the same time giving each side adequate confidence in maintaining its highest goal: assuring an effective nuclear deterrent against nuclear attack.

So it can be said without qualification: we cannot have both deployment of Star Wars and arms control. That was confirmed at Reykjavik.

In sum, I can see no way by which the US deployment of an antiballistic missile defense will strengthen deterrence.

But assume, for a moment, that this were not the case. Is there an alternative means of achieving Henry Kissinger's goal? He fears the Soviets have now, or will achieve in the future, a first-strike capability. It is that which he is trying to offset or prevent. Can that be accomplished at less cost, with greater certainty, and with less risk of fueling the arms race by some means other than SDI?

The Scowcroft Commission, appointed by the President, said yes, based on the simple approach of reducing the ratio of the number of accurate Soviet warheads to the number of US vulnerable land-based missiles. This could be done through negotiation with the Soviet Union or by replacing our potentially vulnerable fixed-base missiles (Minutemen) with mobile missiles (Midgetmen), or by a combination of the two approaches. Gorbachev has already indicated a willingness to move in this direction if we would reduce our threat to his forces by similar moves.

To summarize, none of these rationales for Star Wars II offers a satisfactory approach to reducing the risk of nuclear war in the decades that lie ahead. And they carry the certainty of high cost and a dangerous escalation of the arms race.

We are left, then, to turn to our final option: a reexamination of the military role of nuclear weapons.

\section{WAR PLANS AND ARMS CONTROL AGREEMENTS BASED ON THE BELIEF THAT NUCLEAR WARHEADS ARE NOT USABLE WEAPONS}

Earlier I stated that no one had ever developed a plan for initiating the use of such weapons with benefit to the West. More and more Western military and civilian leaders, including Lord Carver and Lord Mountbatten, Admiral Noel A. Gayler (former Commander in Chief of US Ground, Air, and Sea Forces in the Pacific), and Melvin Laird (Secretary of.Defense in the Nixon Administration) are publicly acknowledging this fact.

If there is a case for NATO retaining its present strategy, that case must rest on the strategy's contribution to the deterrence of Soviet conventional force aggression being worth the risk of nuclear war in the event that deterrence fails.

But as more and more Western political and military leaders recognize, and as they publicly avow, that the launch of strategic nuclear weapons against the Soviet homeland - or even the use of battlefield nuclear weapons - would bring greater destruction to the West than any conceivable contribution they might make to its defense, there is less and less likelihood that the West would authorize the use of any nuclear weapons, except in response to a Soviet nuclear attack. As this diminishing prospect becomes 
more and more widely perceived - and it will - whatever deterrent value still resides in the West's nuclear strategy will diminish still further. One cannot build a credible deterrent on an incredible action.

There are additional factors to be considered. Whether it contributes to deterrence or not, the threat of first use is not without its costs. It is a most contentious policy, leading to divisive debates both within Western Europe and North America; it reduces the West's preparedness for conventional war; and, as I have indicated, it greatly increases the risk of nuclear war.

The costs of whatever deterrent value remains in the West's nuclear strategy are sub. stantial. Could not equivalent deterrence be achieved at lower "cost"? I believe the answer is yes. Compared with the huge risks that we now run by relying on increasingly less credible nuclear threats, recent studies have pointed to ways by which conventional forces may be strengthened at modest military, political, and economic cost.

The West has not done so because there is today no consensus among its military and civilian leaders on the military role of nuclear weapons.

There is, however, a slow but discernible movement toward acceptance of three facts:

- The West's existing plans for initiating the use of nuclear weapons, if implemented, are far more likely to destroy Western Europe, North America, and Japan than to defend them. The Soviet Union faces a similar dilemma.

- Whatever deterrent value remains in the West's nuclear strategy, it is eroding and is purchased at heavy cost.

- The strength, and hence the deterrent capability, of Western conventional forces can be increased substantially within realistic political and financial constraints.

It is on the basis of these facts that I propose both sides accept that nuclear warheads are not weapons - they have no military use whatsoever except to deter one's opponent from their use - and that we base all military plans, defense budgets, weapons development programs, and arms negotiations on the proposition.

The ultimate goal should be a state of mutual deterrence at the lowest force levels consistent with stability.

If the Soviet Union and the United States were to agree, in principal, that each side's nuclear force would be no larger than was needed to deter a nuclear attack by the other, how might the size and composition of such a limited force be determined?

When discussing Gorbachev's proposal for the total elimination of nuclear weapons, I pointed out that a nuclear-free world, while desirable in principal, was infeasible under foreseeable circumstances because the fear of cheating in such an agreement would be very great indeed. I stressed, however, that policing an arms agreement that restricted each side to a small number of warheads is quite feasible with present verification technology. The number required for a force sufficiently large to deter cheating would be determined by the number the Soviets could build without detection by NATO. I know of no studies that point to what that number might be, but surely it would not exceed a few hundred - say, at most, 500 . Very possibly it would be far less. 


\section{CONCLUSION}

I conclude, therefore, that the second half century of the nuclear age need not be a repetition of the first.

We can - indeed, we must - move away from the ad hoc decision making of the past several decades. It is this process that has led to a world in which the two great power blocs, not yet able to avoid continuing political conflict and potential military confrontation, face each other with nuclear warfighting strategies and nuclear arsenals capable of destroying civilization several times over.

Through public debate, a debate in which citizens throughout the world - the potential victims of nuclear war - have both the capability and responsibility to participate, we can reduce the risk of catastrophe by establishing long-term objectives that will underlie and shape all aspects of our nuclear programs. That must be our goal.

Most Americans are simply unaware that Western strategy calls for early initiation of the use of nuclear weapons in a conflict with the Soviets. Eighty percent believe we would not use such weapons unless the Soviets used them first. They would be shocked to learn they are mistaken. And they would be horrified to be told that senior military commanders themselves believe that to carry out our present strategy would lead to destruction of our society.

But those are the facts.

In truth, the Emperor has no clothes. Our present nuclear policy is indeed bankrupt.

President Reagan's intuitive reaction that we must change course - that we must recognize that nuclear warheads cannot be used as military weapons - is correct. To continue as in the past would be totally irresponsible.

When I began this lecture I referred to three crises from my own term as Secretary of Defense: Soviet pressure on Berlin in 1961; the introduction of missiles into Cuba in 1962; and the Middle East War in 1967. My purpose was to provide a personal perspective on one of the central themes of this statement: Things can go wrong. Actions can lead to unintended consequences. Signals can be misread. Technologies can fail. Crises can escalate, even if neither side wants war.

Four recent events - the shooting down of Korean Air Lines Flight 007, leading to the death of 269 civilians; the explosion of the US space shuttle Challenger; the nuclear reactor accident at Chernobyl; and the recent poisonous spoil in the Rhine - reinforce this point. They serve to remind us all how often we are the victims of misinformation, mistaken judgments, and human fallibility. It is inconceivable to me that in a crisis situation, with all its inevitable pressures, decisions regarding the use of nuclear weapons would be unaffected by such factors.

The loss of KAL 007 was a great tragedy. But a similar error in judgment leading to the launch of nuclear weapons would be an unparalleled disaster. We must act to avoid such a disaster by making less and less likely the use of these weapons. The course we have been following for nearly half a century has been taking us precisely in the opposite direction.

The arms negotiations now under way - and particularly the proposals put forward at Reykjavik for reductions in strategic offensive forces - represent an historic opportunity 
to change course and to take the first step toward the long-term goals I have outlined We can lay the foundation for entering the twenty-first century with a totally different nuclear strategy, one of mutual security instead of warfighting; with vastly smaller nuclear forces, no more than 1,000 weapons in place of 50,000; and with a dramatically lower risk that civilization will be destroyed.

We have reached the present dangerous and absurd confrontation by a long series of steps, many of which seemed to be rational in their time. Step by step, we can undo much of the damage.

The program I have presented would, I believe, initiate that process. But whether or not there is acceptance of my specific proposals, we can surely agree on this: we must develop a consensus for a long-term strategy for the second half century of the nuclear age - a strategy that will reduce the unacceptable risks we now face and begin to restore confidence in the future.

Is not our first duty and obligation to assure, beyond doubt, the survival of our civilization? 
5

$\therefore$ 
ROBERT S. McNAMARA

Educated at the University of California and the Harvard Graduate School of Business Administration, Mr. McNamara joined Ford Motor Company in 1946 and became its President in 1960. Just one year later, following the presidential election of John F. Kennedy, he was appointed US Secretary of Defense.

From 1968 to $1981, \mathrm{Mr}$. McNamara was President of the World Bank. In recent years, he has been Director of many US corporations and public institutions and has devoted much of his time to research and writing in the field of arms control. Blundering into Disaster (1986) is his most recent book-length publication.

$\mathrm{Mr}$. McNamara is the recipient of numerous honorary degrees and national and international awards including the Presidential Medal of Freedom, the Albert Einstein Peace Price, and the Dag Hammarskjöld Honorary Medal. 


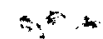




\section{THE INTERNATIONAL INSTITUTE FOR APPLIED SYSTEMS ANALYSIS}

is a nongovernmental research institution, bringing together scientists from around the world to work on problems of common concern. Situated in Laxenburg, Austria, IIASA was founded in October 1972 by the academies of science and equivalent organizations of twelve countries. Its founders gave IIASA a unique position outside national, disciplinary, and institutional boundaries so that it might take the broadest possible view in pursuing its objectives:

To promote international cooperation in solving problems arising from social, economic, technological, and environmental change

To create a network of institutions in the national member organization countries and elsewhere for joint scientific research

To develop and formalize systems analysis and the sciences contributing to it, and promote the use of analytical techniques needed to evaluate and address complex problems

To inform policy advisors and decision makers about the potential application of the Institute's work to such problems

The Institute now has national member organizations in the following countries:

\section{Austria}

The Austrian Academy of Sciences

\section{Bulgaria}

The National Committee for Applied

Systems Analysis and Management

Canada

The Canadian Committee for IIASA

\section{Czechoslovakia}

The Committee for IIASA of the

Czechoslovak Socialist Republic

Finland

The Finnish Committee for IIASA

France

The French Association for the Development of Systems Analysis

\section{German Democratic Republic}

The Academy of Sciences of the German

Democratic Republic

\section{Federal Republic of Germany}

Association for the Advancement of IIASA

\section{Hungary}

The Hungarian Committee for Applied Systems Analysis

Italy

The National Research Council

Japan

The Japan Committee for IIASA

Netherlands

The Foundation IIASA-Netherlands

Poland

The Polish Academy of Sciences

\section{Sweden}

The Swedish Council for Planning and

Coordination of Research

Union of Soviet Socialist Republics

The Academy of Sciences of the Union of Soviet Socialist Republics

United States of America

The American Academy of Arts and Sciences 